\title{
Somatic cell selection for chlorsulfuron- resistant mutants in potato: identification of point mutations in the acetohydroxyacid synthase gene
}

Philippa J. Barrell', Julie M. Latimer ${ }^{1}$, Samantha J. Baldwin ${ }^{1}$, Michelle L. Thompson' ${ }^{1}$, Jeanne M.E. Jacobs ${ }^{1,2}$ and Anthony J. Conner ${ }^{2,3^{*}}$

\begin{abstract}
Background: Somatic cell selection in plants allows the recovery of spontaneous mutants from cell cultures. When coupled with the regeneration of plants it allows an effective approach for the recovery of novel traits in plants. This study undertook somatic cell selection in the potato (Solanum tuberosum L.) cultivar 'Iwa' using the sulfonylurea herbicide, chlorsulfuron, as a positive selection agent.

Results: Following 5 days' exposure of potato cell suspension cultures to $20 \mu \mathrm{g} / \mathrm{l}$ chlorsulfuron, rescue selection recovered rare potato cell colonies at a frequency of approximately one event in $2.7 \times 10^{5}$ of plated cells. Plants that were regenerated from these cell colonies retained resistance to chlorsulfuron and two variants were confirmed to have different independent point mutations in the acetohydroxyacid synthase (AHAS) gene. One point mutation involved a transition of cytosine for thymine, which substituted the equivalent of Pro-197 to Ser-197 in the AHAS enzyme. The second point mutation involved a transversion of thymine to adenine, changing the equivalent of Trp-574 to Arg-574. The two independent point mutations recovered were assembled into a chimeric gene and binary vector for Agrobacterium-mediated transformation of wild-type 'Iwa' potato. This confirmed that the mutations in the AHAS gene conferred chlorsulfuron resistance in the resulting transgenic plants.

Conclusions: Somatic cell selection in potato using the sulfonylurea herbicide, chlorsulfuron, recovered resistant variants attributed to mutational events in the AHAS gene. The mutant AHAS genes recovered are therefore good candidates as selectable marker genes for intragenic transformation of potato.
\end{abstract}

Keywords: Acetohydroxyacid synthase, Acetolactate synthase, Chlorsulfuron resistance, Intragenic selectable marker, Potato, Somatic cell selection, Sulfonylurea resistance

\section{Background}

Somatic cell selection in plants applies the principles of microbial genetics to plant cell cultures. In this manner a selection pressure is imposed on a large population of cultured cells so that only rare individuals with a specific phenotype are capable of survival or growth [1]. Effective use of this technology allows

\footnotetext{
*Correspondence: tony.conner@agresearch.co.nz

2Bio-Protection Research Centre, Lincoln University, PO Box 85084, Lincoln 7647, New Zealand

${ }^{3}$ AgResearch Ltd, Lincoln Research Centre, Private Bag 4749, Christchurch

8140, New Zealand

Full list of author information is available at the end of the article
}

the recovery of spontaneous mutants from cell cultures with the potential recovery of novel traits with agricultural applications in crop plants. The high aptitude of potato (Solanum tuberosum L.) for performance in cell culture and the ease of shoot regeneration, offers the opportunity for employing this approach for somatic improvement [2].

Despite this potential, somatic cell selection has generated only a few examples of novel traits in potato. These include cell lines with resistance to culture filtrates of Fusarium oxysporum [3] and high salt concentration [4]. The most important 
application of somatic cell selection in potato improvement involves the development of clones with resistance to common scab disease incited by Streptomyces scabiei $[5,6]$. The use of thaxtomin A (the pathotoxin of S. scabiei) as a selection agent on cultured cells allowed the recovery of rare resistant cell lines that could be regenerated into plants with improved resistance to common scab disease following both greenhouse and field evaluation [6,7].

Herbicide resistance is another important trait in crop plants with applications for weed control, crop management and seed production [8]. Herbicides such as the sulfonylureas and imidazolinones target the acetohydroxyacid synthase enzyme (AHAS) [also known as acetolactate synthase (ALS)], thereby preventing the biosynthesis of branched chain amino acids, resulting in plant death [9]. Chemical mutagenesis and subsequent breeding have yielded plants with sulfonylurea and imidazolinone resistance in wheat (Triticum aestivum), barley (Hordeum vulgare), sugarcane (Saccharum spp.) and rice (Oryza sativa) [10-13], as well as forage brassicas including swede $(B$. napus), rape (B. napus) and turnips (B. rapa) [14]. Furthermore, biotypes of 159 plant species have evolved resistance to AHAS-inhibitors globally [15]. In most cases resistance to AHAS-inhibitor herbicides is due to point mutations in the coding region of the AHAS gene $[9,16]$. AHAS genes with these point mutations have been shown to confer resistance to sulfonylureaand imidazolinone-based herbicides when transformed into plants [17-21]. Somatic cell selection has also been used to select for resistance to sulfonylurea herbicides in tobacco (Nicotiana tabacum) [22] and sugarbeet (Beta vulgaris) [23, 24].

This study provides another example of successfully producing a novel trait in potato (resistance to the sulfonylurea herbicide, chlorsulfuron) using somatic cell selection. Rare cell colonies were recovered following exposure of cultured potato cells to a concentration of the sulfonylurea herbicide, chlorsulfuron, which normally inhibits cell growth. Plants regenerated from these cell colonies retained resistance to chlorsulfuron and two variants were confirmed to have different point mutations in the AHAS gene. The two independent point mutations recovered were assembled into a chimeric gene and binary vector for Agrobacteriummediated transformation. Wild-type potato cultivar 'Iwa' was transformed with this vector and the resulting plants were confirmed to exhibit chlorsulfuron resistance. This validates the point mutations identified in the potato $A H A S$ gene to be the source of resistance to chlorsulfuron and provides a potato-derived selectable marker gene to facilitate intragenic/cisgenic gene transfer to potato $[25,26]$.

\section{Methods}

\section{Plant material}

Micropropagated virus-free plants of potato cultivar 'Iwa' were maintained as previously described [27] on plant multiplication (PM) medium consisting of MS salts and vitamins [28] plus $30 \mathrm{~g} / \mathrm{l}$ sucrose, $40 \mathrm{mg} / \mathrm{l}$ ascorbic acid and $500 \mathrm{mg} / \mathrm{l}$ casein hydrolysate. After the $\mathrm{pH}$ was adjusted to 5.8 with $0.1 \mathrm{M} \mathrm{KOH}, 8 \mathrm{~g} / \mathrm{l}$ agar was added and the medium was autoclaved at $121{ }^{\circ} \mathrm{C}$ for $15 \mathrm{~min}$. Aliquots of $50 \mathrm{ml}$ were dispensed into pre-sterilized plastic containers $(80 \mathrm{~mm}$ diameter $\times 50 \mathrm{~mm}$ high; Vertex Plastics, Hamilton, New Zealand). Plants were routinely subcultured as two- to three-node segments every three-four weeks and grown at $26{ }^{\circ} \mathrm{C}$ under cool white fluorescent lamps $\left(80-100 \mu \mathrm{mol} / \mathrm{m}^{2} / \mathrm{s} ; 16-\mathrm{h}\right.$ photoperiod). To define culture conditions and chlorsulfuron concentrations for effective cell selection, initial experiments were conducted on micropropagated potato plants in PM medium with and without casein hydrolysate and supplemented with 0 to $20 \mu \mathrm{g} / \mathrm{l}$ chlorsulfuron (filter sterilized). In some experiments $100 \mathrm{mM}$ each of leucine, isoleucine and valine (filter sterilized) was added to the culture medium.

\section{Cell culture and selection}

Three weeks after the previous subculture, callus cultures were initiated from stem internodes $(c a .1 \mathrm{~cm}$ long) cut in half lengthways and placed face down on potato callus induction (CI) medium, composed of the PM medium supplemented with $2 \mathrm{mg} / \mathrm{l}$ BAP and $0.2 \mathrm{mg} / \mathrm{l} \mathrm{NAA}$ and dispensed as $25 \mathrm{ml}$ aliquots into standard plastic Petri dishes $(9 \mathrm{~cm}$ diameter $\times 1 \mathrm{~cm}$ high). After four weeks' incubation in darkness at $22{ }^{\circ} \mathrm{C}$, stems showing good callus production were transferred to $40 \mathrm{ml}$ of liquid CI medium in $100 \mathrm{ml}$ Erlenmeyer flasks and incubated on an orbital shaker (110 rpm) for 5 days. To remove stem material and clumps of callus tissue, the resulting cell culture was poured through a stainless steel sieve $(0.5 \mathrm{~mm}$ pores $)$ mounted over a series of $50 \mathrm{~mL}$ Falcon $^{\text {tw }}$ tubes and left standing until a clear line of separation was visible to determine the cell suspension volume. The supernatant was discarded and the settled cells resuspended in four volumes of fresh CI medium without casein hydrolysate. The cycle of cell settling and resuspension was then repeated, with the culture medium supplemented with $20 \mu \mathrm{g} / \mathrm{l}$ chlorsulfuron (filter sterilized). The cell suspension was incubated for 5 days on an orbital shaker as described above.

\section{Variant recovery and plant regeneration}

The chlorsulfuron-treated cells were allowed to settle in $50 \mathrm{ml}$ Falcon tubes, cell density was adjusted to about $10^{5}$ plating units per $\mathrm{ml}$, and $0.5 \mathrm{ml}$ was plated onto CI medium in standard Petri dishes for the recovery of 
surviving potato cells. To assist the rescue of putative rare chlorsulfuron-resistant variant potato cells, a nurse culture of Nicotiana plumbaginifolia cells, cultured as previously described [29], was established by plating $0.8 \mathrm{ml}$ of a cell suspension culture $\left(10^{5}\right.$ plating units per $\mathrm{ml}$ ) directly onto a fresh plate of CI medium. A piece of sterile $7 \mathrm{~cm}$ diameter Whatman No. 1 filter paper was placed over the plated N. plumbaginifolia cells, with the chlorsulfuron-treated potato cells being plated on top of the filter paper. The plated cells were grown at $26{ }^{\circ} \mathrm{C}$ under cool white fluorescent lamps $\left(30-40 \mu \mathrm{mol} / \mathrm{m}^{2} / \mathrm{s}\right.$; 16-h photoperiod). After two-three months, rescued potato cell colonies were transferred to callus regeneration medium (PM medium with sucrose reduced to $5 \mathrm{~g} / \mathrm{l} \mathrm{su}-$ crose, plus $1 \mathrm{mg} / \mathrm{l}$ zeatin and $5 \mathrm{mg} / \mathrm{l} \mathrm{GA}_{3}$, both filter sterilized) and incubated under reduced light intensity $\left(10 \mu \mathrm{mol} / \mathrm{m}^{2} / \mathrm{s} ; 16-\mathrm{h}\right.$ photoperiod) at $26{ }^{\circ} \mathrm{C}$ for a further two-three months with calli being transferred to fresh media every four-five weeks. The first regenerated shoot from each variant was transferred to PM medium for micropropagation and subsequent screening for chlorsulfuron resistance.

\section{PCR isolation of the AHAS gene from wild-type potato cultivar 'Iwa'}

Genomic DNA was isolated from in vitro shoots of the potato cultivar 'Iwa' and the variants CR06 and CR27 derived from 'Iwa', based on the method previously described [30].

The primers AHAS1F (5' TAGCCATTTTGCCTCC TTTC 3') and AHAS1R (5' CAACGGCAAACTAGA CAGATAGAA 3') were used to amplify wild-type potato cultivar 'Iwa' AHAS coding sequences via PCR. Reactions consisted of 1x PWO buffer and 2.5U PWO (Roche Diagnostics N.Z., Ltd. Auckland New Zealand), $20 \mathrm{mM}$ $\mathrm{MgSO}_{4}, 0.2 \mathrm{mM}$ each dNTP, $0.1 \mu \mathrm{M}$ AHAS1F, $0.1 \mu \mathrm{M}$ AHAS1R, and 50 ng Iwa DNA. PCR conditions included an initial denaturing step of $94{ }^{\circ} \mathrm{C}$ for $2 \mathrm{~min}, 10$ cycles of $94{ }^{\circ} \mathrm{C}$ for $15 \mathrm{~s}, 59{ }^{\circ} \mathrm{C}$ for $30 \mathrm{~s}, 72{ }^{\circ} \mathrm{C}$ for $2 \mathrm{~min}$. A further 20 cycles of $94{ }^{\circ} \mathrm{C}$ for $15 \mathrm{~s}, 59{ }^{\circ} \mathrm{C}$ for $30 \mathrm{~s}$ and $72{ }^{\circ} \mathrm{C}$ for 2 min followed with an extension of $5 \mathrm{~s}$ per cycle and a 7 min $72{ }^{\circ} \mathrm{C}$ final extension step. Amplified products were separated by electrophoresis in a $1 \%$ agarose gel in 1xTAE buffer and visualized under UV light after staining with ethidium bromide.

\section{Cloning and sequencing of PCR products}

PCR fragments of approximately $2 \mathrm{~kb}$ were extracted from agarose gel using a QIAquick gel extraction kit (QIAGEN, Hilden, Germany) and ligated into the pGEM ${ }^{\circ}$-T Easy vector (Promega, Mannheim, Germany). The ligation reactions were transformed into Subcloning Efficiency $^{\mathrm{TM}}$ DH5 $\alpha^{\mathrm{TM}}$ Competent Cells (Invitrogen, Carlsbad, CA, USA) according to manufacturer's instructions. Transformations were plated on LB media supplemented with $100 \mathrm{mg} / \mathrm{l}$ ampicillin, $100 \mathrm{mM} / \mathrm{l}$ isopropyl $\beta$-D-1-thiogalactopyranoside (IPTG) and $20 \mathrm{mg} / \mathrm{l} \mathrm{X}$-gal. Plasmid DNA from 16 white colonies from wild-type 'Iwa' were isolated using High Pure Plasmid Isolation Kit (Roche Applied Science) and sequenced using Applied Biosystems BigDye ${ }^{\bullet}$ Terminator v3.1 kit. Initial sequencing reactions were performed with M13 forward and reverse primers. Further sequencing primers were designed within the AHAS sequence as follows (5'-3') ALSWALKER1: TGTACG CCAAATCAAAAA; AHASF: GCCTCACCATCTCCA TGTTT; Alsprom: CGATGATGATGGGTGTGGGTG AGA; ALS5\#2: CCTCGGCACTTGACGGCTAA; ALS5\#3: AAAACGCTTCACGAACAACC; als3\#3: GAAGCCATCCCTCCACAATA; ALS3\#2: TTAGGAG CAATGGGATTTGG; ALSterm: GGGCCATACTTGT TGGATGT; AHAS1R: CAACGGCAAACTAGACA GATAGAA; AHASR: CCGTCTTATGCCAACCATTT. Sequencing reactions were analyzed using an $\mathrm{ABI}$ 3130xl automated sequencer (Applied Biosystems, Foster City, USA).

\section{Binary vector construction and plant transformation}

A chimeric AHAS gene was designed to incorporate the two point mutations in the AHAS coding region uncovered by the somatic cell selection experiments. The modified AHAS coding region was designed to be flanked by the promoter and terminator regions of the Lhca3 gene from potato cultivar 'Iwa' that we have previously described [31]. The AHAS coding sequence flanked by the Lhca3 promoter and terminator was obtained from Genscript Corporation (Piscataway, NJ, USA) as a fragment ligated into the plasmid pUC57. The chimeric AHAS gene was removed from the pUC57 backbone by digestion with the enzyme $M l u \mathrm{I}$. The fragment was blunt-ended and ligated into the binary vector pMOA33 [32], previously digested with the blunt cutting enzyme PmeI. Ligation reactions were transformed into E. coli strain DH5 $\alpha$. Plasmid DNA isolated from transformed $E$. coli colonies was digested with the restriction enzyme $E c o$ RI to identify the orientation of the inserted fragment. A binary vector with the nptII selectable marker gene and the chimeric AHAS gene in the same orientation was identified and named pMOA33AHAS. The binary vector was transferred to the disarmed Agrobacterium tumefaciens strain EHA105 [33]. Agrobacterium-mediated transformation of virus-free potato cultivar 'Iwa' plantlets was performed following our standard method [34]. Kanamycin (100 mg/l) was used as the selection agent, and regenerated plants were challenged with media containing $20 \mu \mathrm{g} / \mathrm{l}$ chlorsulfuron to assess their ability for roots to grow into the media containing chlorsulfuron. 


\section{Molecular assessment of regenerated plants}

Genomic plant DNA was extracted using a Macherey-Nagel NucleoSpin ${ }^{\odot}$ Plant II Kit. (Düren, Germany). The primers (5'-3') pMOA33RBFor: CCCAGTAGCTGACATTCATC; and StCabAHAS SeqRev: CCCCTCCCCTTCTCTTATGTGTA were used in PCRs to confirm transgenic status with an expected $370 \mathrm{bp}$ amplicon spanning the Lhca3 terminator of the construct into the nos promoter of the selectable marker from the binary vector pMOA33 [32]. The same DNA samples were also assessed via PCR for the presence of Agrobacterium using primers based on the virG gene producing a predicted amplicon of $692 \mathrm{bp}$ [31].

\section{Results}

Recovery of chlorsulfuron-resistant potato plants

Initial experiments investigated the influence of culture medium composition and chlorsulfuron concentrations on in vitro potato plants (Additional file 1: Figure S1). The presence of up to $20 \mu \mathrm{g} / \mathrm{l}$ chlorsulfuron in the standard PM medium containing casein hydrolysate inhibited, but did not prevent, root development on in vitro potato plants. However, upon omission of casein hydrolysate, the toxicity of chlorsulfuron was substantially greater with no root formation observed in medium with $20 \mu \mathrm{g} / \mathrm{l}$ chlorsulfuron. Supplementing the latter medium with branched chain amino acids (leucine, isoleucine and valine) mitigated the toxic effects of chlorsulfuron.

A dose response experiment using PM medium without casein hydrolysate determined that $20 \mu \mathrm{g} / \mathrm{l}$ chlorsulfuron was the lowest concentration that prevented root development on all plants (Additional file 2: Figure S2). Similar experiments were repeated with leaf and stem explants placed on CI medium with and without casein hydrolysate. This confirmed that in the absence of casein hydrolysate, $20 \mu \mathrm{g} / \mathrm{l}$ chlorsulfuron completely inhibited callus induction from these explants, whereas only a very slight callus growth was observed at $10 \mu \mathrm{g} / \mathrm{l}$ chlorsulfuron. As expected, the inclusion of branched chain amino acids (leucine, isoleucine and valine) in the medium substantially reduced the toxic effects of chlorsulfuron, whereas the presence of casein hydrolysate partially alleviated the toxicity.

The exposure of potato cells to $20 \mu \mathrm{g} / \mathrm{l}$ chlorsulfuron in suspension culture for five days prior to plating on $\mathrm{CI}$ medium resulted in the complete inhibition of the background growth of wild-type cells during the first month of incubation. After two to three months of incubation, rare variant cell colonies were observed (Figure 1A). A total of 42 variant cell colonies were recovered from 64 Petri dishes, of which 22 retained chlorsulfuron resistance upon a further subculture cycle (Table 1). Eighteen of these variants with stable resistance to chlorsulfuron as callus cultures were successfully regenerated into plants (Fig. 1b), of which 12 continued to exhibit resistance to chlorsulfuron as whole plants (Table 1, Fig. 2). The variants CR06, CR27 and CR34 exhibited the highest degree of resistance to chlorsulfuron as judged by developing the longest roots on culture medium supplemented with $20 \mu \mathrm{g} / \mathrm{l}$ chlorsulfuron (Fig. 2). The variant CR34 displayed atypical shoot morphology with thin spindly stems and small curved leaves and was not investigated further.

\section{AHAS sequence results from potato cultivar 'Iwa' and the chlorsulfuron-resistant plants}

DNA sequencing of the AHAS gene amplified from potato cultivar 'Iwa' revealed a 1980 bp gene composed of a single exon with no introns and encoding a predicted protein of 659 amino acids. The sequencing revealed three distinct alleles in 'Iwa', with the sequence of one allele deposited in GenBank (Accession HM114275).

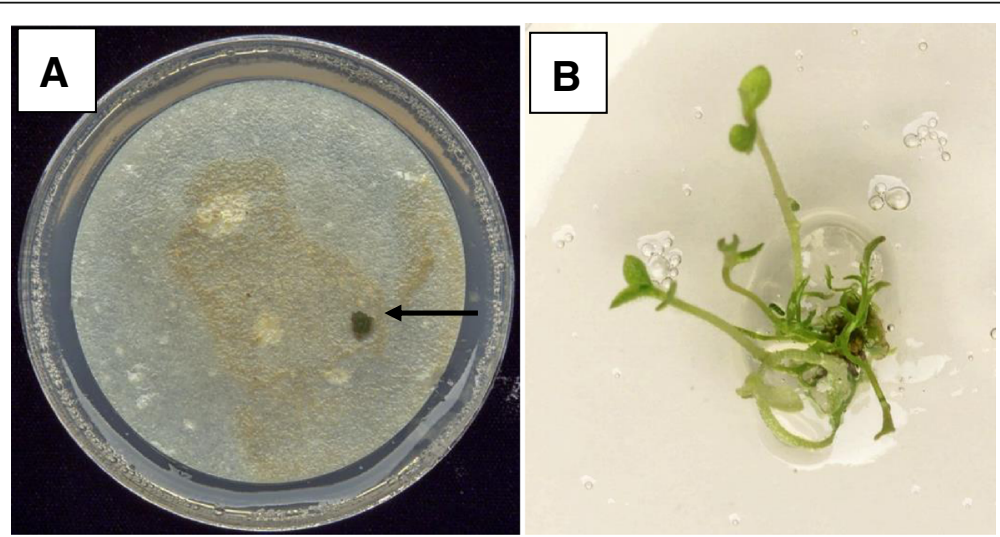

Fig. 1 Somatic cell selection and regeneration of chlorsulfuron resistance in potato. a The arrow indicates a rare potato cell colony rescued from cell suspension culture growing on media containing $20 \mu \mathrm{g} / \mathrm{l}$ chlorsulfuron (each Petri dish was seeded with approximately $5 \times 10^{4}$ cells) b An in vitro potato plant regenerated from a cell colony with resistance to chlorsulfuron 
Table 1 Summary of variants rescued following exposure of somatic cells of potato to chlorsulfuron

\begin{tabular}{ll}
\hline Number of selection plates $^{\mathrm{a}}$ & 64 \\
Number of variant colonies initially recovered & 42 \\
Number of variants retaining chlorsulfuron resistance & 22 \\
Number of variants regenerating plants & 18 \\
Number of variants with chlorsulfuron-resistant plants & \\
\hline
\end{tabular}

${ }^{a}$ Each plate was seeded with $5 \times 10^{4}$ potato cells previously exposed to $20 \mu \mathrm{g} / \mathrm{l}$ chlorsulfuron

${ }^{\mathrm{b}}$ See Fig. 2

Interrogation of version 4.03 of the potato genome database $[35,36]$ revealed three matches of accession HM114275 to the diploid reference potato genome sequence of DM1-3 516 R44 ('DM'), on chromosomes 3, 6 and 7 (Additional file 3: Figure S3). The locus on DM chromosome 6 showed only partial alignment with bases 985-2028 of accession HM114275. Our sequence derived from 'Iwa' (Accession HM114275) showed 99.5\% identity to the locus on DM chromosome 3, with only 95.4\% identity to the locus on chromosome 7 .

PCR amplification and DNA sequencing of the $A H A S$ coding region from plants regenerated from cell colonies CR06 and CR27 uncovered two separate point mutations (Fig. 3). In CR06, a transition mutation occurred at position 556 with the substitution of cytosine for thymine, which changes the 186th amino acid from a proline into a serine residue. Whereas in CR27 a transversion mutation occurred at position 1687 with the substitution of thymine with adenine, changing the 563rd amino acid from tryptophan to arginine.
Potato transformation with an AHAS sequence containing the two point mutations

The coding region of the potato AHAS gene used for transformation was designed to encompass the two point mutations identified from CR06 and CR27 (Additional file 4: Figure S4). This sequence with the regulatory controls of the potato Lhca3 gene was synthesized and the resulting chimeric gene inserted into a binary vector to produce pMOA33AHAS (Additional file 5: Figure S5). Agrobacterium-mediated transformation of potato with pMOA33AHAS using kanamycin as the selective agent yielded 15 independently regenerated kanamycin-resistant plants. Potato transformation using the same vector with chlorsulfuron as the selective agent failed to produce chlorsulfuron-resistant plants.

All 15 kanamycin resistant-plants were confirmed to contain the chimeric $A H A S$ gene by PCR with the amplification of a $370 \mathrm{bp}$ fragment (data not shown). The PCR reactions performed using primers to amplify virG from Agrobacterium were all negative and showed that there was no contaminating Agrobacterium DNA in the plant DNA samples (data not shown). The majority of the transgenic lines (12 of 15) exhibited root growth on in vitro plants when challenged on media containing 20 $\mathrm{ug} / \mathrm{ml}$ chlorsulfuron, with five lines $(\# 2,5,11,14$, and 15) exhibiting substantial root growth (Fig. 4).

\section{Discussion}

This study reports the development of a somatic cell selection system using chlorsulfuron as a positive selection agent to generate herbicide resistance in potato plants.

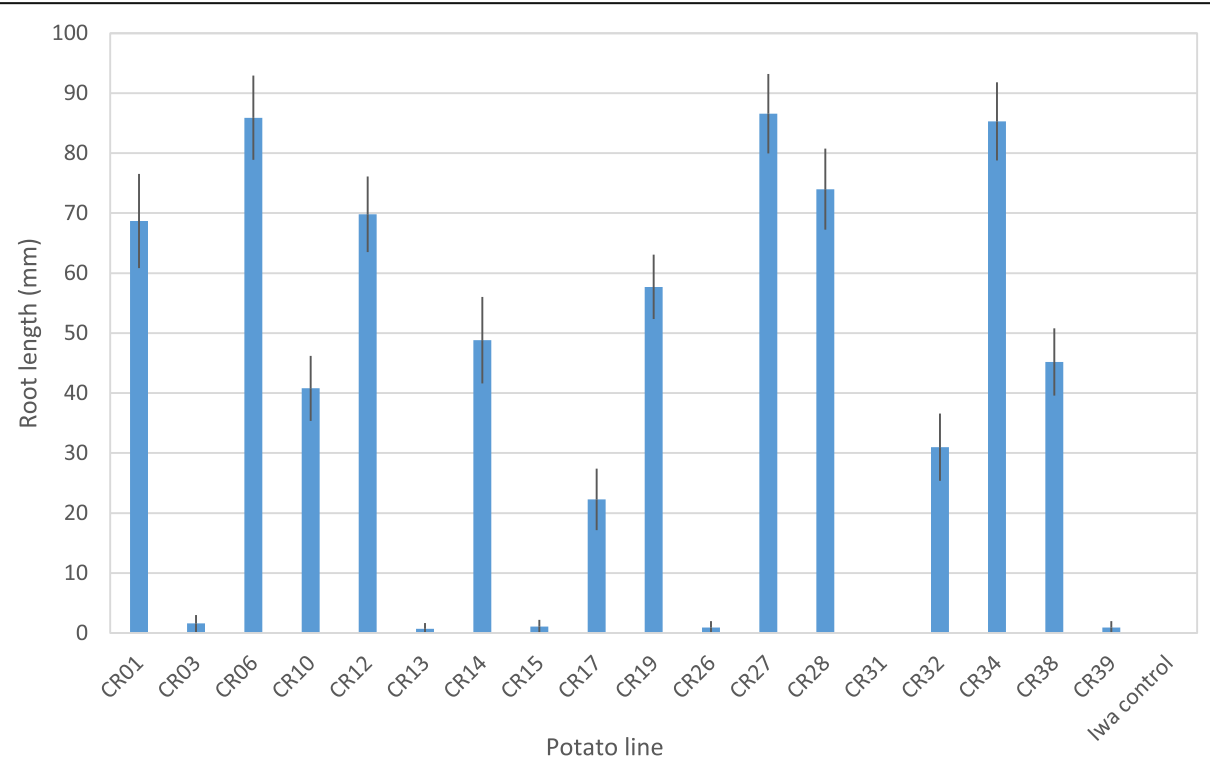

Fig. 2 Root length of plants from regenerated cell colonies. Length of longest root on micropropagated plants (mean \pm standard deviation; $n=10$ ) after 3 weeks cultured on PM medium (without casein hydrolysate) plus 20 mg/l chlorsulfuron. The twelve resistant variants were: CR01, CR06, CR10, CR12, CR14, CR17, CR19, CR27, CR28, CR32, CR34, and CR38. 'Iwa' control plants did not form roots into the media 


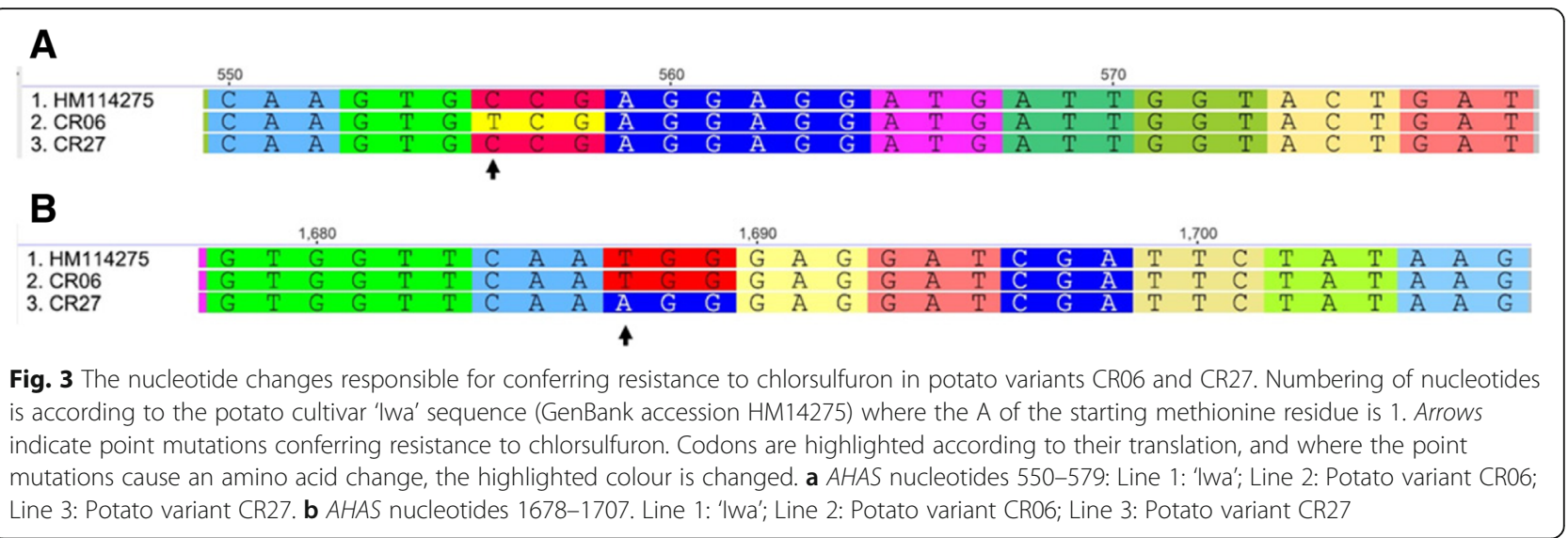

The approach used involved a rescue selection strategy with cell suspension cultures being exposed to the selection agent for five days prior to plating onto a medium without selection for the recovery of surviving variant cell colonies (Fig. 1a). The advantages of a rescue selection approach are the uniform exposure of cells to the selection agent and the rapid recovery of resistant variants on a standard medium [1].

Effective somatic cell selection in plants depends on defining the lowest concentration of the selection agent that completely prevents the growth of all wild-type cells. A key component for establishing an effective somatic cell selection approach for chlorsulfuron resistance in potato involved understanding the interaction between the culture medium and the selection agent. Cell culture media for many plant species often include complex ingredients; in the case of potato, a common ingredient is casein hydrolysate (e.g. [17, 27]), a complex mixture that includes amino acids. Chlorsulfuron was more toxic to potato cultures in the absence of casein hydrolysate or branched chain amino acids (Additional file 1: Figure S1). The alleviation of chlorsulfuron toxicity by supplementing the culture medium with branched chain amino acids is well documented [37]. This is expected given that the target site for chlorsulfuron and related herbicides is acetohydroxyacid

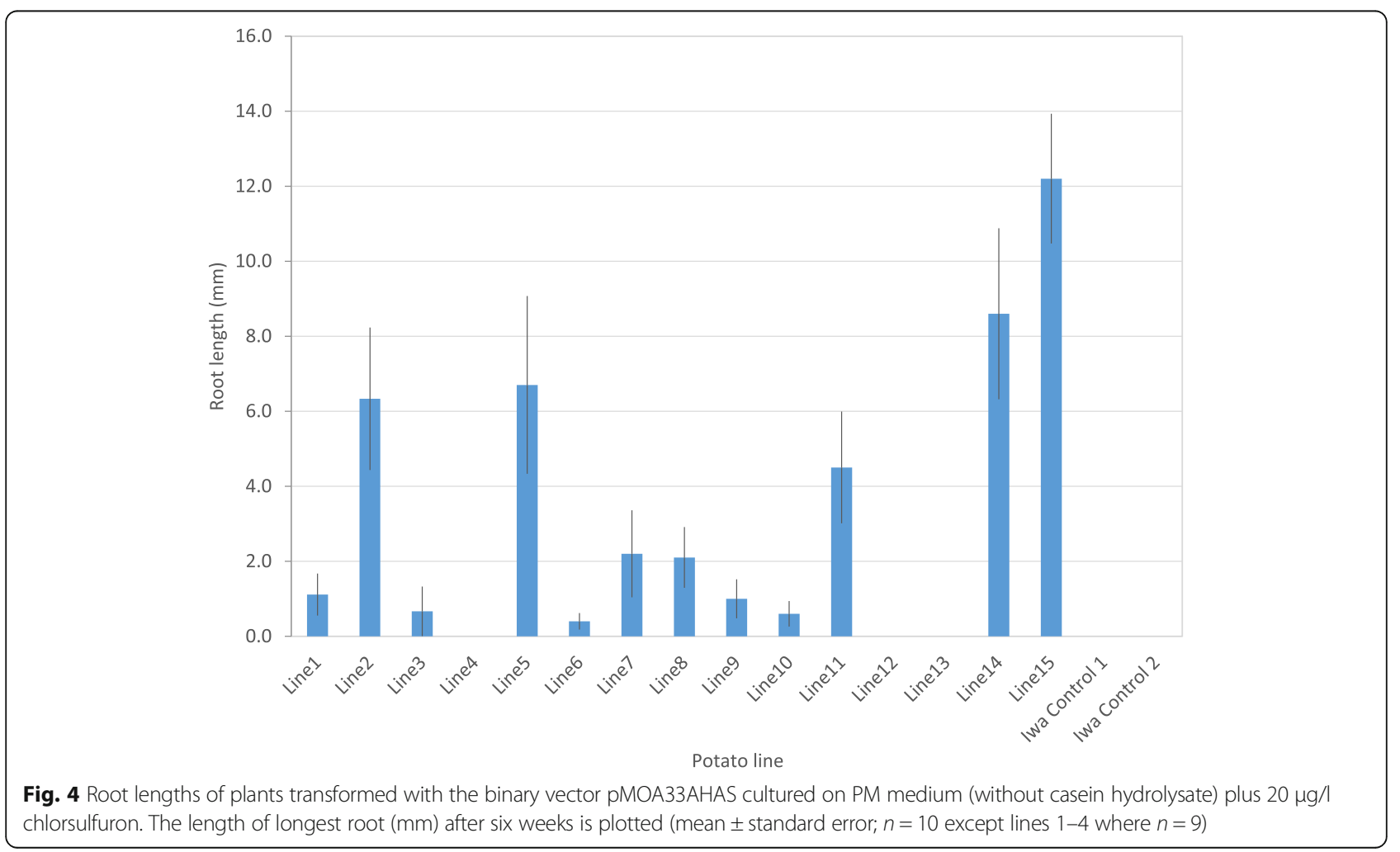


synthase, the first enzyme in the pathway for biosynthesis of branched chain amino acids [9]. The omission of casein hydrolysate from the culture medium is therefore essential during the selection and subsequent characterization of variants for chlorsulfuron resistance in potato. This is consistent with the need to omit casein hydrolysate from the culture medium when using the bar gene as a selectable marker for potato transformation with phosphinothricin as the selection agent [38].

Following rescue selection, assessment of variant stability and plant regeneration 12 variants continued to exhibit resistance to chlorsulfuron as whole plants (Table 1, Fig. 2). These 12 variant plants with chlorsulfuron resistance were recovered from a total of 64 selection plates each seeded with 50,000 cells. This represents approximately one event in $2.7 \times 10^{5}$ somatic cells plated. This frequency is consistent with effective somatic cell selection in plants [1], and very similar to the rescue selection approach used for thaxtomin A resistance in potato $[5,6]$.

The highest degree of chlorsulfuron resistance was observed in potato variants CR06, CR27 and CR34 (Fig. 2). The plants of one of these variants (CR34) grew poorly and exhibited unusual shoot morphology, presumably as a consequence of undesirable somaclonal changes during the cell culture phase of somatic cell selection. Such events are common during plant tissue culture [1] and are frequently reported in regenerated potato clones in addition to desired genetic change [34]. Further analysis of the potato variants therefore focused on CR06 and CR27 in order to establish a mutational basis for the phenotypic change of higher chlorsulfuron resistance. Resistance to sulfonylurea herbicides, such as chlorsulfuron, is usually associated with point mutations in the AHAS gene resulting in amino acid substitutions that prevent or reduce herbicide binding to the AHAS enzyme [9]. We therefore sequenced the $A H A S$ gene from the potato cultivar 'Iwa', then repeated this for the CR06 and CR27 variants derived from 'Iwa'.

The sequence of the coding region of the AHAS gene from 'Iwa' (GenBank accession HM114275) showed the closest match to a locus on potato chromosome 3 (Additional file 1: Figure S1). At this locus the sequencing revealed three distinct alleles in 'Iwa', with one of the alleles presumably in the duplex state for an autotetraploid potato cultivar. Sequencing the AHAS coding region from variant plants designated CR06 and CR27 revealed that each possessed different independent point mutations of significance for explaining the resistance to AHAS-inhibitors (Fig. 3). This confirms that CR06 and CR27 are derived from mutation events with at least one of the four alleles in tetraploid potato conferring herbicide resistance in the expected dominant condition.
For AHAS it is common practice to standardize amino acid number to the Arabidopsis thaliana sequence [9, 16]. Pro-186 and Trp-563 in potato correspond to Pro-197 and Trp-574 in A. thaliana. The vast majority of species with resistance to AHASinhibitors have amino acid substitutions at either of these two sites $[9,16]$. The Pro-197 to Ser-197 mutations, as found in CR06 potato in this study, is very common across many species [16]. This mutation is known to prevent chlorsulfuron binding to AHAS and to have no effect on AHAS enzyme kinetics and functionality [39]. At Trp-574, a substitution to Leu-574 is the most frequent recorded mutation for resistance to AHAS-inhibitors across many species [16], although many other amino acid substitutions have been recorded in this position, including Arg-574 as found in CR27 in this study [9].

The point mutations revealed in variants CR06 and CR27 result in amino acid substitutions that are well known to confer resistance to AHAS-inhibitor herbicides $[9,16]$. Introduction of a gene with these mutations back into wild-type potato cultivar 'Iwa' using Agrobacterium-mediated transformation with a binary vector confirmed that the mutations in the AHAS gene conferred chlorsulfuron resistance in the resulting transgenic plants (Fig. 4). This therefore establishes that the variants recovered via somatic cell selection in potato can be attributed to mutational events.

Similar to the results on potato in this study, somatic cell selection for chlorsulfuron resistance in tobacco [22] was determined to result from mutations causing amino acid substitutions equivalent to Pro-197 and Trp-574 in the AHAS gene [40]. Mutations at both sites were capable of independently conferring resistance to chlorsulfuron, whereas the combination of both amino acid changes led to a higher level of resistance to chlorsulfuron [40]. Therefore, we decided to combine the two point mutations identified in our potato somatic cell selection experiments into a single construct for our transformation experiments. A synthetic DNA sequence was assembled combining both point mutations recovered from our somatic cell selection experiments into the AHAS coding region (Additional file 4: Figure S4) flanked by the promoter and 3' terminator regions of the potato Lhca 3 gene. This chimeric intragene was ligated into the binary vector pMOA33 which has a nptII selection marker gene conferring kanamycin resistance [32]. The resulting pMOA33AHAS was used in Agrobacterium-mediated transformation with both kanamycin and chlorsulfuron as selective agents in separate transformation experiments with 'Iwa'. Transgenic plants were recovered as expected using kanamycin as a selection agent. However, we did not recover transgenic plants using chlorsulfuron as a selective agent with 
pMOA33AHAS. This may be a consequence of the mutant AHAS gene not expressing well in cell and tissue culture due to the Lhca 3 promoter which has light- and leaf-specific expression [41, 42].

The transgenic plants obtained using kanamycin as a selection agent were resistant to chlorsulfuron, as judged by the growth of roots into media containing chlorsulfuron compared with no roots on the wild-type control plants (Fig. 4). We observed that the root length of transgenic plants containing the pMOA33AHAS T-DNA that were challenged on media containing chlorsulfuron was substantially shorter than the variant plants isolated from the cell selection experiments (Figs. 2 and 4). We hypothesize that the differences may be due to the promoters driving the mutant $A H A S$ gene in each group of potato plants. Interrogation of the supplementary data published with the potato genome sequence [35] reveals that members of the Lhca3 gene family are at much reduced expression compared with the AHAS genes in tuber, stolon and root tissues (data not shown). As the potato Lhca3 gene is light-induced and leaf-specific [41, 42], the reduced root length for the transgenic lines compared with the variant lines following cell selection is expected. The marked variation in root length among the independently derived transgenic lines, with five transgenic lines having substantially higher chlorsulfuron resistance (Fig. 4), is probably a consequence of transgene position effects following plant transformation $[43,44]$ rather than expression driven by the Lhca3 promoter.

Agrobacterium-mediated plant transformation traditionally involves the transfer of bacterial and other nonplant DNA into plants [26]. One of the concerns of the general public about this technology involves the transfer of genetic material between species that cannot normally hybridize [25, 45, 46]. Intragenic and cisgenic technologies have been developed to address the concerns of "crossing the species barrier" in the construction of transformed plants. Both intragenic and cisgenic strategies involve the transfer of DNA derived from the species own gene pool $[25,26,45,47,48]$. One of the limiting steps for developing intragenic and cisgenic plants is the availability of selectable marker genes for transformation [25, 26]. The mutant AHAS genes recovered in this study are good candidates as a selectable marker gene for intragenic transformation of potato.

\section{Conclusion}

The sulfonylurea herbicide, chlorsulfuron, was used as a positive selection agent for somatic cell selection in the potato cultivar 'Iwa'. This recovered rare potato cell colonies at a frequency of approximately one event in $2.7 \times 10^{5}$ of plated cells and plants regenerated from these cell colonies retained resistance to chlorsulfuron. Two variants were found to have different independent point mutations in the AHAS gene. Agrobacterium-mediated transformation of wild-type 'Iwa' potato with a chimeric gene containing the two mutations confirmed that they conferred chlorsulfuron resistance. The mutant AHAS genes provide candidates as selectable marker genes for intragenic transformation of potato.

\section{Additional files}

Additional file 1: Figure S1. Influence of culture medium composition and chlorsulfuron concentrations on in vitro plants of wild-type potato cultivar 'Iwa'. Root length was measured after three weeks with mean root length $(\mathrm{mm}) \pm$ standard deviation plotted $(n=30)$. PM $0=$ potato multiplication media, no chlorsulfuron; PM $10=$ potato multiplication media, $10 \mu \mathrm{g} / \mathrm{l}$ chlorsulfuron; PM 20 = potato multiplication media, $20 \mu \mathrm{g} /$ I chlorsulfuron; PM -ch 0 = potato multiplication media, no casein hydrolysate, no chlorsulfuron; PM -ch $10=$ potato multiplication media, no casein hydrolysate, $10 \mu \mathrm{g} / \mathrm{l}$ chlorsulfuron; PM -ch 20 = potato multiplication media, no casein hydrolysate, $20 \mu \mathrm{g} / \mathrm{l}$ chlorsulfuron; $\mathrm{PM}-\mathrm{ch}+$ aa $0=$ potato multiplication media, no casein hydrolysate, amino acids, no chlorsulfuron; PM-ch + aa 10: potato multiplication media, no casein hydrolysate, amino acids, $10 \mu \mathrm{g} / \mathrm{l}$ chlorsulfuron; PM-ch + aa 20 = potato multiplication media, no casein hydrolysate, amino acids, $20 \mu \mathrm{g} / \mathrm{l}$ chlorsulfuron; amino acids refers to the presence of $100 \mathrm{mM}$ each of leucine, isoleucine and valine. (DOCX $16 \mathrm{~kb}$ )

Additional file 2: Figure S2. A dose response experiment of chlorsulfuron on growth of wild-type potato cultivar 'Iwa' using PM medium without casein hydrolysate. Root length was measured after three weeks with mean root length $(\mathrm{mm}) \pm$ standard deviation plotted $(n=30)$. (DOCX $15 \mathrm{~kb})$

Additional file 3: Figure S3. Alignment of the coding sequence of the wild-type potato cultivar 'Iwa' AHAS allele (GenBank accession HM114275) and partial DNA BAC sequences from the reference potato genome [35, 36]. Line 1: PGSC0003DMB000000227, which maps to chromosome 6; Line 2: PGSC0003DMB000000368, which maps to chromosome 3; Line 3: PGSC0003DMB000000096 which maps to chromosome 7; and Line 4: The coding region of the AHAS allele from 'Iwa', GenBank accession HM114275. (DOCX 1863 kb)

Additional file 4: Figure S4. Nucleotide sequence of the mutated potato AHAS coding region. The two nucleotides highlighted in red are the point mutations identified in the somatic cell selection experiments from cell colonies CR06, CR27. The first mutation, the highlighted residue at nucleotide 556 was originally $C$ and was converted to a $T$, which changes the 186th amino acid from a proline into a serine residue. The second highlighted residue was identified to have a mutation at position 1687, where a T residue was converted to A, which changed the 563rd amino acid from tryptophan into an arginine residue. (DOCX $12 \mathrm{~kb}$ )

Additional file 5: Figure S5. The binary vector pMOA33-AHAS. The locations of the primers pMOA33RBFor and StCabAHASSeqRev used to confirm transgenic status of the regenerated plants are indicated. (DOCX 68 kb)

\section{Abbreviations \\ AHAS: acetohydroxyacid synthase; ALS: Acetolactate synthase; Cl: Callus induction; PCR: Polymerase chain reaction; PM: Plant multiplication}

\section{Acknowledgements}

We thank Barbara Bione and Carolin Fleischer for assisting with the somatic cell selection experiments; Mathijn de Boer for assisting with the cloning and sequencing experiments; Susan Thomson for help interrogating the Potato Genome Sequence; and Mary Christey and Ed Morgan for comments on earlier drafts of the manuscript.

\section{Funding}

This work was partially funded by Ministry of Business, Innovation and Employment (New Zealand) contract C02X0805 to The New Zealand Institute for Plant \& Food Research Ltd. 


\section{Availability of data and materials}

The datasets used and/or analyzed during the current study are available from the corresponding author on reasonable request.

\section{Authors' contributions \\ PJB designed and supervised the vector construction and transformation experiments, performed bioinformatics analyses and interrogation of the potato genome sequence, and wrote the manuscript. JML and MLT constructed the binary vector, undertook the potato transformation, characterized and maintained the transgenic lines. SJB cloned and sequenced the potato AHAS gene. JMEJ conceived the study, collated the cell selection and variant characterization data, and wrote the manuscript. AJC conceived the study, undertook the cell selection and variant characterization, and wrote the manuscript. All authors edited and approved the final manuscript.}

\section{Competing interests}

AJC is a plant biotechnology associate editor for BMC Biotechnology. He has played no editorial role in this paper.

\section{Consent for publication}

Not applicable.

\section{Ethics approval and consent to participate}

Not applicable.

\section{Publisher's Note}

Springer Nature remains neutral with regard to jurisdictional claims in published maps and institutional affiliations.

\section{Author details}

'The New Zealand Institute for Plant \& Food Research Limited, Private Bag 4704, Christchurch 8140, New Zealand. 'Bio-Protection Research Centre, Lincoln University, PO Box 85084, Lincoln 7647, New Zealand. ${ }^{3}$ AgResearch Ltd, Lincoln Research Centre, Private Bag 4749, Christchurch 8140, New Zealand.

Received: 21 March 2017 Accepted: 1 June 2017

\section{Published online: 06 June 2017}

\section{References}

1. Conner AJ, Meredith CP. Genetic manipulation of plant cells. In: Marcus A editor. The biochemistry of plants: A comprehensive treatise; vol. 15, Molecular Biology. Orlando: Academic; 1989. p. 653-88.

2. Barrell PJ, Meiyalaghan S, Jacobs JME, Conner AJ. Applications of biotechnology and genomics in potato improvement. Plant Biotechnol J. 2013:11:907-20.

3. Behnke M. Selections of dihaploid potato callus for resistance to the culture filtrates of Fusarium oxysporum. Z Pflanzenzüchtung. 1980;85:254-8.

4. Queiros F, Fidalgo F, Santos I, Salema R. In vitro selection of salt tolerant cell lines in Solanum tuberosum L. Biol Plant. 2007;51:728-34.

5. Wilson CR, Luckman GA, Tegg RS, Yuan ZQ, Wilson AJ, Eyles A, Conner AJ. Enhanced resistance to common scab of potato through somatic cell selection in CV. Iwa with the phytotoxin thaxtomin A. Plant Pathol. 2009;58:137-44.

6. Wilson CR, Tegg RS, Wilson AJ, Luckman GA, Eyles A, Yuan ZQ, Hingston LH, Conner AJ. Stable and extreme resistance to common scab of potato obtained through somatic cell selection. Phytopathology. 2010;100:460-7.

7. Tegg RS, Thangavel T, Aminian H, Wilson CR. Somaclonal selection in potato for resistance to common scab provides concurrent resistance to powdery scab. Plant Pathol. 2013:62:922-31.

8. Conner AJ, Field RJ. Herbicide-resistant crops: A new approach to an old problem or a radical new tool? In: McLean G, Evans G, editors. Herbicideresistant crops and pastures in Australian farming systems. Canberra: Bureau of Resource Sciences; 1995. p. 53-71.

9. Yu Q, Powles SB. Resistance to AHAS inhibitor herbicides: current understanding. Pest Manage Sci. 2014;70:1340-50.

10. Newhouse KE, Smith WA, Starrett MA, Schaefer TJ, Singh BK. Tolerance to imidazolinone herbicides in wheat. Plant Physiol. 1992;100:882-6.

11. Lee H, Rustgi S, Kumar N, Burke I, Yenish JP, Gill KS, von Wettstein D, Ullrich SE. Single nucleotide mutation in the barley acetohydroxy acid synthase (AHAS) gene confers resistance to imidazolinone herbicides. Proc Natl Acad Sci U S A. 2011;108:8909-13.
12. Koch AC, Ramgareeb S, Rutherford RS, Snyman SJ, Watt MP. An in vitro mutagenesis protocol for the production of sugarcane tolerant to the herbicide imazapyr. In Vitro Cell Dev Biol Plant. 2012;48:417-27.

13. Croughan TP. Herbicide resistant rice. United States Patent No. 5,736,629. 1998.

14. Dumbleton A, Gowers S, Conner A, Christie M, Kenny P, Mulcock H, Charteris B. Cleancrop ${ }^{\mathrm{TM}}$ brassica system: The development of herbicide resistant brassica crops for New Zealand farming systems. Proc N Z Grassl Assoc. 2012;74:25-30.

15. International survey of herbicide-resistant weeds. 2017. http://www. weedscience.org. Accessed 4 Mar 2017

16. Mutations in herbicide resistant weeds to ALS inhibitors. 2017. http://www. weedscience.org. Accessed 4 Mar 2017

17. Andersson M, Trifonova A, Andersson AB, Johansson M, Bulow L, Hofvander P. A novel selection system for potato transformation using a mutated AHAS gene. Plant Cell Rep. 2003:22:261-7.

18. Kolkman JM, Slabaugh MB, Bruniard JM, Berry S, Bushman BS, Olungu C, Maes N, Abratti G, Zambelli A, Miller JF, et al. Acetohydroxyacid synthase mutations conferring resistance to imidazolinone or sulfonylurea herbicides in sunflower. Theor Appl Genet. 2004;109:1147-59.

19. Le DT, Yoon MY, Tae Kim Y, Choi JD. Two consecutive aspartic acid residues conferring herbicide resistance in tobacco acetohydroxy acid synthase. Biochim Biophys Acta. 1749;2005:103-12.

20. Olszewski NE, Martin FB, Ausubel FM. Specialized binary vector for plant transformation: expression of the Arabidopsis thaliana AHAS gene in Nicotiana tabacum. Nucleic Acids Res. 1988;16:10765-82.

21. Haughn GW, Smith J, Mazur B, Somerville C. Transformation with a mutant Arabidopsis acetolactate synthase gene renders tobacco resistant to sulfonylurea herbicides. Mol Gen Genet. 1988;211:266-71.

22. Chaleff RS, Ray TB. Herbicide-resistant mutants from tobacco cell cultures. Science. 1984:223:1148-51.

23. Wright TR, Bascomb NF, Sturner SF, Penner D. Biochemical mechanism and molecular basis for ALS-inhibiting herbicide resistance in sugarbeet (Beta vulgaris) somatic cell selections. Weed Sci. 1998;46:13-23.

24. Saunders JW, Acquaah G, Renner KA, Doley WP. Monogenic dominan sulfonylurea resistance in sugar beet from somatic cell selection. Crop Sci. 1992;32:1357-60.

25. Barrell PJ, Jacobs JME, Baldwin SJ, Conner AJ. Intragenic vectors for plant transformation within gene pools. CAB Reviews: Perspectives in Agriculture, Veterinary Science, Nutrition and Natural Resources. 2010;5(No. 010):1-18.

26. Conner AJ, Barrell PJ, Baldwin SJ, Lokerse AS, Cooper PA, Erasmuson AK, Nap JP, Jacobs JME. Intragenic vectors for gene transfer without foreign DNA. Euphytica. 2007;154:341-53.

27. Conner AJ, Williams MK, Gardner RC, Deroles SC, Shaw ML, Lancaster JE. Agrobacterium-mediated transformation of New Zealand potato cultivars. N Z J Crop Hortic Sci. 1991;19:1-8.

28. Murashige T, Skoog F. A revised medium for rapid growth and bio assays with tobacco tissue cultures. Physiol Plant. 1962:15:473-97.

29. Conner AJ, Meredith CP. Strategies for the selection and characterisation of aluminium-resistant variants from cell cultures of Nicotiana plumbaginifolia. Planta. 1985;166:466-73.

30. Bernatzky R, Tanksley SD. Genetics of actin-related sequences in tomato. Theor Appl Genet. 1986;72:314-21.

31. Meiyalaghan S, Thomson SJ, Fiers MWEJ, Barrell PJ, Latimer JM, Mohan S, Jones EE, Conner AJ, Jacobs JME. Structure and expression of GSL1 and GSL2 genes encoding gibberellin stimulated-like proteins in diploid and highly heterozygous tetraploid potato reveals their highly conserved and essential status. BMC Genomics. 2014;15:2.

32. Barrell PJ, Conner AJ. Minimal T-DNA vectors suitable for agricultural deployment of transgenic plants. Biotechniques. 2006:41:708-10.

33. Hood EE, Gelvin SB, Melchers LS, Hoekema A. New Agrobacterium helper plasmids for gene transfer to plants. Transgenic Res. 1993;2:208-18.

34. Barrell PJ, Conner AJ. Facilitating the recovery of phenotypically normal transgenic lines in clonal crops: a new strategy illustrated in potato. Theor Appl Genet. 2011;122:1171-7.

35. The Potato Genome Sequencing Consortium. Genome sequence and analysis of the tuber crop potato. Nature. 2011;475:189-95.

36. Sharma SK, Bolser D, de Boer J, Sonderkaer M, Amoros W, Carboni MF, D'Ambrosio JM, de la Cruz G, Di Genova A, Douches DS, et al. Construction of reference chromosome-scale pseudomolecules for potato: Integrating the potato genome with genetic and physical maps. G3 (Bethesda). 2013;3:2031-47. 
37. Ray TB. Site of action of chlorsulfuron: inhibition of valine and isoleucine biosynthesis in plants. Plant Physiol. 1984;75:827-31.

38. Barrell PJ, Shang YJ, Cooper PA, Conner AJ. Alternative selectable markers for potato transformation using minimal T-DNA vectors. Plant Cell Tiss Org Cult. 2002;70:61-8.

39. Yu Q, Han HP, Vila-Aiub MM, Powles SB. AHAS herbicide resistance endowing mutations: effect on AHAS functionality and plant growth. J Exp Bot. 2010;61:3925-34.

40. Lee KY, Townsend J, Tepperman J, Black M, Chui CF, Mazur B, Dunsmuir P, Bedbrook J. The molecular basis of sulfonylurea herbicide resistance in tobacco. EMBO J. 1988;7:1241-8.

41. Meiyalaghan S, Jacobs JME, Butler RC, Wratten SD, Conner AJ. Expression of cry $1 \mathrm{Ac} 9$ and $\mathrm{cry} 9 \mathrm{Aa} 2$ genes under a potato light-inducible Lhca3 promoter in transgenic potatoes for tuber moth resistance. Euphytica. 2006;147:297-309.

42. Nap JP, van Spanje M, Dirkse WG, Baarda G, Mlynarova L, Loonen A Grondhuis P, Stiekema WJ. Activity of the promoter of the Lhca3.St.1 gene, encoding the potato apoprotein 2 of the light-harvesting complex of Photosystem I, in transgenic potato and tobacco plants. Plant Mol Biol. 1993;23:605-12.

43. Mlynarova L, Loonen A, Heldens J, Jansen RC, Keizer P, Stiekema WJ, Nap JP. Reduced position effect in mature transgenic plants conferred by the chicken lysozyme matrix-associated region. Plant Cell. 1994;6:417-26.

44. Nap J-P, Keizer P, Jansen R. First-generation transgenic plants and statistics. Plant Mol Biol Rep. 1993;11:156-64.

45. Holme IB, Wendt T, Holm PB. Intragenesis and cisgenesis as alternatives to transgenic crop development. Plant Biotechnol J. 2013;11:395-407.

46. Myskja BK. The moral difference between intragenic and transgenic modification of plants. J Agric Environ Ethics. 2006;19:225-38.

47. Espinoza C, Schlechter R, Herrera D, Torres E, Serrano A, Medina C, ArceJohnson P. Cisgenesis and intragenesis: new tools for improving crops. Biol Res. 2013;46:323-31.

48. Kim CY, Ahn YO, Kim SH, Kim YH, Lee HS, Catanach AS, Jacobs JME, Conner AJ, Kwak SS. The sweet potato IbMYBI gene as a potential visible marker for sweet potato intragenic vector system. Physiol Plant. 2010;139:229-40.

\section{Submit your next manuscript to BioMed Central and we will help you at every step:}

- We accept pre-submission inquiries

- Our selector tool helps you to find the most relevant journal

- We provide round the clock customer support

- Convenient online submission

- Thorough peer review

- Inclusion in PubMed and all major indexing services

- Maximum visibility for your research

Submit your manuscript at www.biomedcentral.com/submit

) Biomed Central 